\title{
Process of spontaneous resolution in the conservative management of congenital dacryocystocele
}

This article was published in the following Dove Press journal:

Clinical Ophthalmology

26 February 2014

Number of times this article has been viewed

\author{
Masashi Mimura ${ }^{1,2}$ \\ Mari Ueki' \\ Hidehiro Oku' \\ Bunpei Sato ${ }^{2}$ \\ Tsunehiko Ikeda' \\ 'Department of Ophthalmology, \\ Osaka Medical College, Takatsuki, \\ ${ }^{2}$ Department of Ophthalmology, \\ Osaka Kaisei Hospital, Osaka, Japan
}

Correspondence: Masashi Mimura Department of Ophthalmology, Osaka Medical College, 2-7 Daigaku-machi, Takatsuki, Osaka 569-8686, Japan

$\mathrm{Tel}+8 \mid 72683$ |22।

Fax +81726818195

Email optl19@poh.osaka-med.ac.jp
Purpose: To assess efficacy of the conservative management of patients with congenital dacryocystocele.

Materials and methods: This was a retrospective case series involving six sides of five infants with a dacryocystocele treated at Osaka Kaisei Hospital, Osaka, Japan. The conservative management protocol consisted of the application of warm compresses and massage over the mass, with the addition of antibiotics when dacryocystitis developed. Patient age at the time of resolution, presence of retrograde outflow of contents of dacryocystoceles from the puncta, and development of dacryocystitis were recorded.

Results: The dacryocystocele was unilateral in four patients and bilateral in one patient. A nasal cyst was present in four patients without respiratory distress. The median patient age at the time of the diagnosis was 7 days (range 2-10 days). Conservative management was selected in all patients, and the dacryocystocele was resolved in all patients at a median patient age of 14.5 days (range 11-105 days). Two sides developed dacryocystitis, which resolved in a few days with antibiotic treatment. In those two sides, rupture of the dacryocystoceles to the common canaliculus with retrograde discharge of the contents from the puncta before the dacryocystitis developed was noted. For the other four treated sides, no such discharge or development of dacryocystitis was observed.

Conclusion: The findings of this study show that a dacryocystocele has a good chance of resolving spontaneously with conservative management and careful observation, and that rupture of the dacryocystocele to the common canaliculus might be an important precursor of dacryocystitis.

Keywords: dacryocystitis, congenital lacrimal obstruction, remnant, precursor, retrograde discharge

\section{Introduction}

A congenital dacryocystocele is a rare variant of congenital tear-duct obstruction, with an incidence of $0.7 \%$ in all infants, ${ }^{1} 0.02 \%$ in newborns, ${ }^{2}$ and $0.1 \%$ in infants with congenital nasolacrimal duct obstruction. ${ }^{3}$ It usually presents as a dark-blue, cystic enlargement in the area of the lacrimal sac, and is due to a prenatal enlargement of the lacrimal sac or nasolacrimal duct. Moreover, studies have shown that it can occasionally extend into the nasal cavity and cause respiratory distress. ${ }^{4,5}$ A congenital nasolacrimal duct obstruction reportedly will resolve spontaneously with nonsurgical management in more than $80 \%$ of newborns during their first year of life $; 3,6,7$ however, the optimal treatment for congenital dacryocystoceles is still controversial. ${ }^{2,4,5,8-11}$ Schnall and Christian reported that $76 \%$ (16 of 21 ) of the dacryocystoceles in their study resolved within 2 
weeks with a nonsurgical treatment protocol consisting of warm compresses and massage, ${ }^{12}$ whereas Becker recommended early surgical intervention due to the fact that $37.9 \%$ (eleven of 29) of the eyes with dacryocystoceles in that study developed dacryocystitis. ${ }^{8}$

On the other hand, regardless of the type of treatment selected, studies have shown that the problem of eyes with dacryocystocele is that they have a greater tendency to develop dacryocystitis or cellulitis than do eyes with congenital nasolacrimal duct obstruction..$^{2,4,8-11}$ It has been reported that in eyes with congenital nasolacrimal duct obstruction, $2.9 \%$ of the cases developed acute dacryocystitis in the first year of life, ${ }^{13}$ while $37.9 \%-74 \%$ of eyes with dacryocystocele developed dacryocystitis. ${ }^{8,9,11}$ Campolattaro et al reported that in more than $80 \%$ of the neonatal eyes with acute dacryocystitis, it arose from a dacryocystocele. ${ }^{14}$

In our hospital, we prefer a conservative treatment for dacryocystoceles with a careful observation of any infectious signs, thus allowing us to follow the natural course of the disorder. In this study, we investigated this conservative treatment protocol for the treatment of dacryocystoceles, as well as the signs that indicate that dacryocystitis will develop.

\section{Materials and methods}

We reviewed the medical records of six consecutive eyes of five infants who were diagnosed with dacryocystocele in our hospital. The diagnosis of dacryocystocele was made by noting the presence of a dark-blue mass in the medial canthal region, at or soon after birth. Computed tomography (CT) was performed to confirm the diagnosis of dacryocystocele and to exclude meningoencephalocele, sudoriferous cyst, dermoid cyst, or other lacrimal system abnormalities. ${ }^{15-17}$ A conservative management protocol was selected for all dacryocystoceles, which consisted of warm compresses and gentle digital massage of the lacrimal sac. Topical and systemic antibiotics were administered when needed, depending on the severity of the inflammation.
Patient age at onset, the presence of retrograde outflow of contents of the dacryocystoceles from the puncta, patient age at resolution, and development of dacryocystitis were recorded. This study was performed in accordance with the tenets set forth in the Declaration of Helsinki, and prior informed consent was obtained from the parents of all patients for the conservative treatment.

\section{Results}

All of the masses were diagnosed as congenital dacryocystoceles, and the presence of a nasal cyst under the inferior turbinate was detected by CT scan in four of the six eyes (Table 1). Of the five infants, four were boys and one was a girl, and the dacryocystocele was bilateral in one patient and unilateral in the other four. Of the four unilateral patients, the dacryocystocele was located in the right nasal passage in three patients and in the left nasal passage in one. The median patient age at the time of the diagnosis was 7 days (range 2-10 days). All of the infants were born at full term, and none presented any respiratory distress. The Apgar score at 5 minutes was $9-10$ points in all patients. No other malformations were found in any infants.

We selected a conservative treatment for all eyes, and all dacryocystoceles were found to be resolved at 11-105 days, with a median patient age of 14.5 days. In two eyes of two patients, the dacryocystoceles progressed to dacryocystitis, with a swollen lacrimal sac, yellow discharge from the puncta, and redness of the skin around the lacrimal sac. In both patients, topical and systemic antibiotics were administered, and the dacryocystitis resolved within several days. In those two patients, it was noted that a rupture of the dacryocystocele to the common canaliculus with retrograde discharge of mucoid fluid from the puncta had occurred prior to the development of the dacryocystitis. The other four patients did not show such retrograde discharges from the puncta and did not develop dacryocystitis.

Table I Clinical details of five patients with dacryocystocele

\begin{tabular}{|c|c|c|c|c|c|c|c|c|}
\hline Patient & Sex & $R / L$ & $\begin{array}{l}\text { Age of spontaneous } \\
\text { resolution (days) }\end{array}$ & $\begin{array}{l}\text { Reflux from } \\
\text { puncta }\end{array}$ & Dacryocystitis & Antibiotics & $\begin{array}{l}\text { Follow-up } \\
\text { (months) }\end{array}$ & $\begin{array}{l}\text { Intranasal } \\
\text { cyst }\end{array}$ \\
\hline I & $M$ & $\mathrm{R}$ & 12 & - & - & - & 14 & + \\
\hline \multirow[t]{3}{*}{2} & $M$ & $\mathrm{R}$ & 14 & - & - & Topical & 18 & Unknown \\
\hline & & $L$ & 105 & + & + & Topical & & \\
\hline & & & & & & Oral & & \\
\hline \multirow[t]{2}{*}{3} & $M$ & $R$ & 11 & + & + & Topical & 15 & + \\
\hline & & & & & & Intravenous & & \\
\hline 4 & $M$ & $\mathrm{~L}$ & 15 & - & - & - & 16 & + \\
\hline 5 & $\mathrm{~F}$ & $\mathrm{R}$ & 18 & - & - & - & 17 & + \\
\hline
\end{tabular}

Abbreviations: $M$, male; $F$, female; $R$, right; L, left; +, yes; -, no. 


\section{Case without dacryocystitis (patient I)}

A 5-day-old male infant was referred to us due to the observation of a dark-blue soft mass in the region of his left lacrimal sac (Figure 1). Examination by ultrasonography confirmed the mass to be a $1 \mathrm{~cm}$-diameter cyst in the lacrimal sac. No other problems occurred with this case during delivery. A CT scan showed that both the left lacrimal sac and nasolacrimal duct were swollen, and the extension of the nasolacrimal duct formed a nasal cyst that occluded the left inferior nasal meatus (Figure 2). A diagnosis of congenital dacryocystocele was made, and because the infant did not have epiphora, eye discharge, or any signs of infection, we selected to treat him with warm massage. On day 12 , the dacryocystocele completely disappeared, with no signs as mucoid fluid reflux from the left punctum. No recurrence of the dacryocystocele was found during the 14-month follow-up period.

\section{Case with dacryocystitis (patient 2)}

A male infant with a dark-blue soft mass in the region of both lacrimal sacs at birth was examined by a local doctor at 2 days of age. He was healthy during the perinatal period and had no other complications. When we saw this case in our hospital at 10 days of age, the parents reported that the mass in the right lacrimal sac had disappeared at 7 days of age with no signs of mucoid fluid reflex from the right punctum or other symptoms. We followed the mass in the left lacrimal sac with a conservative treatment protocol with a continuation of topical antibiotics (tobramycin) prescribed by his local doctor. At 83 days of age, the left dacryocystocele was found to be reduced, with a retrograde reflux of clear mucoid fluid from both the superior and inferior puncta dur-

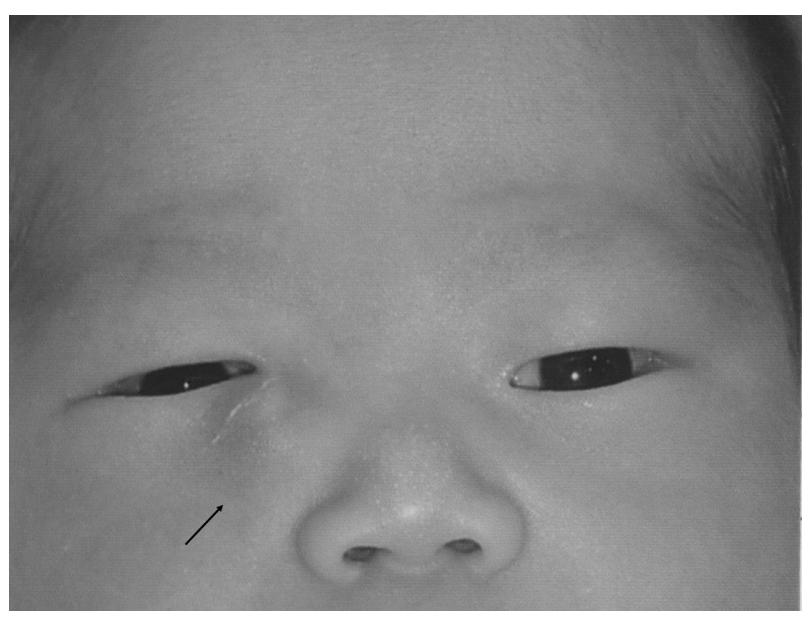

Figure I Image showing a large dacryocystocele causing an upward tilt of the inner canthus of the right palpebral fissure (arrow) in patient I, a 5-day-old male infant. ing local massage. After 2 weeks, dacryocystitis developed, with an enlargement of the lacrimal sac and redness of the skin around the dacryocystocele, and discharge of pus from the puncta was also noted. We continued the conservative treatment, but added a daily administration of oral cefditoren pivoxil $(3 \mathrm{mg} / \mathrm{kg})$ with careful observation. The pus discharge stopped within a few days, and the dacryocystocele resolved at 105 days of age. No recurrence was seen during the 18-month follow-up period.

In all five patients, complete resolution was observed, and no recurrence was noted during the median follow-up period of 16 months (range 14-18 months).

\section{Discussion}

The present study showed that a dacryocystocele has a good chance of resolving spontaneously with conservative management and careful observation, and that rupture of the dacryocystocele to the common canaliculus might be an important precursor to developing dacryocystitis.

Dacryocystoceles are believed to develop due to a persistent membrane at the valve of Hasner that leads to an accumulation of amniotic fluid or tears, and that this accumulation causes a functional obstruction of the common canaliculus or the valve of Rosenmüller secondarily. ${ }^{18}$ However, a congenital nasolacrimal duct obstruction does not progress secondarily to a dacryocystocele with such a proximal obstruction. Sevel examined serial histological sections of the orbits of 54 fetuses, and found that a persistent membrane formed by epithelial remnants is likely to remain not only at the junction between the lacrimal sac and the nasolacrimal duct but also at the junction of the canaliculus with the lacrimal sac. ${ }^{19}$ The postmortem examination of a 59-day-old infant with a dacryocystocele by Silverman showed that there was an absence of a connection between the canaliculus and the lacrimal sac. ${ }^{20}$ These observations suggested that a proximal obstruction might be formed by remnants similar to the distal obstruction, and that a dacryocystocele is a cyst that develops from the early stage of canalization of the lacrimal passage. Moreover, Yazici et al were able to diagnose a congenital dacryocystocele by magnetic resonance imaging in a fetus at 27 weeks of gestation that corresponded to the time of canalization of the lacrimal passage, ${ }^{1}$ which is in good agreement with the hypothesis that a dacryocystocele develops as a cyst during its morphosis. Thus, we believe that a dacryocystocele has a good chance of resolving spontaneously with the opening of the proximal and distal remnants, as in patients with congenital nasolacrimal duct obstructions. 


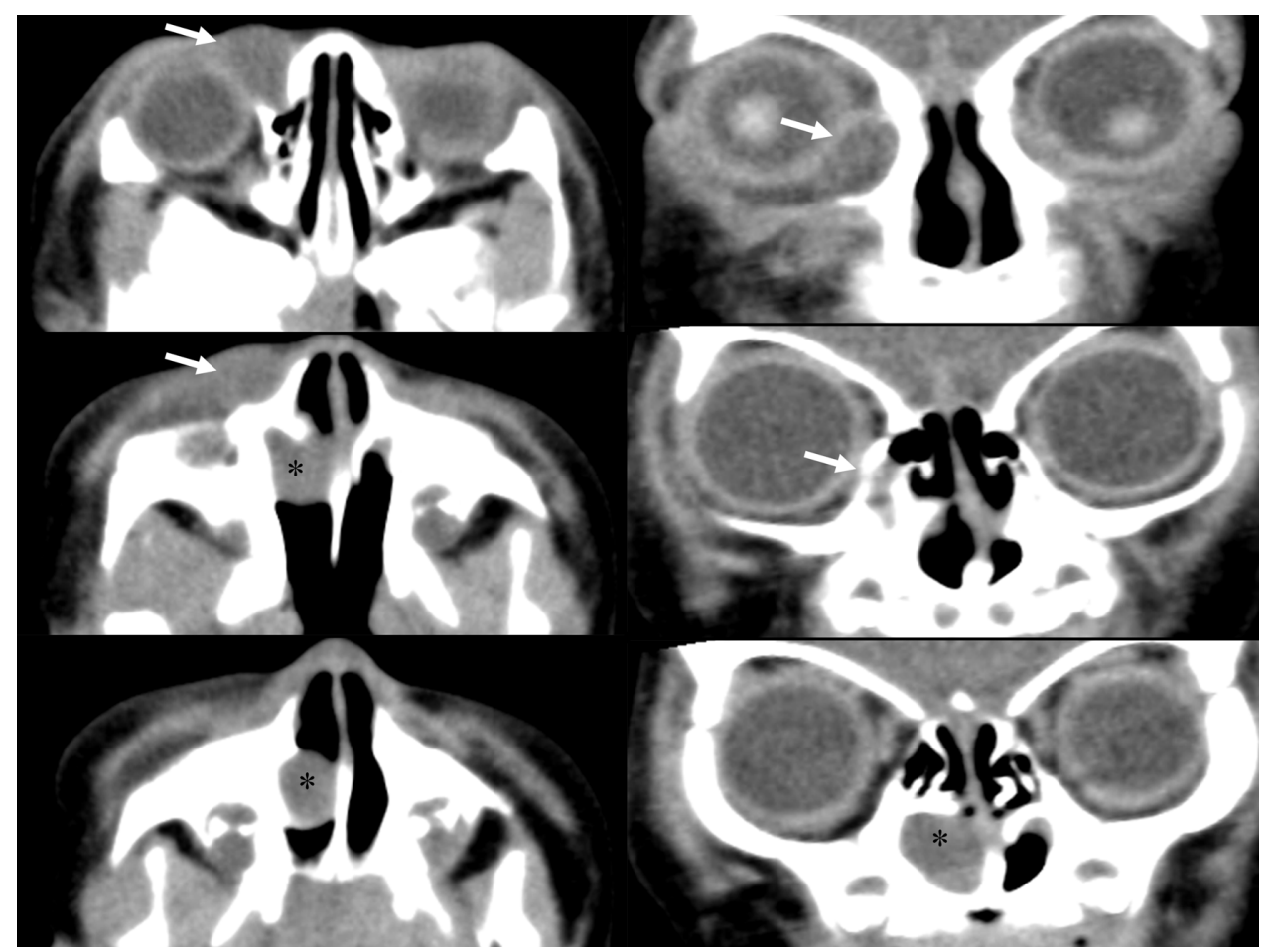

Figure 2 Computed tomography scan images showing the dacryocystocele (arrows) in patient I. The dacryocystocele formed consecutive nasal cysts (asterisks), which occluded the left inferior nasal meatus.

A spontaneous resolution of the dacryocystocele would be expected after the disappearance of the proximal and distal obstructions. Therefore, there are two possible courses for the resolution of a dacryocystocele. When the proximal obstruction opens earlier than the distal obstruction, the dacryocystocele will rupture to the common canaliculus, with the contents flowing out through the puncta. This also means that there is a passage of tears with bacterial flora from the conjunctival sac into the lacrimal system, which could then lead to dacryocystitis. On the other hand, an earlier opening of the distal obstruction, which means rupture of the dacryocystocele to the nasal cavity, will show no symptoms and does not induce downward infection from the conjunctival sac. Thus, there should be less of a chance of dacryocystitis under this condition. This would explain the course of spontaneous resolution in our six dacryocystoceles. With our conservative treatment, we found that the patients with a rupture of the dacryocystocele with reflux of mucoid fluid from the puncta developed dacryocystitis, while the other patients without such reflux did not develop dacryocystitis. The two reports by Mansour et al and Harris and DiClementi showed similar dacryocystocele cases that resolved spontaneously before surgical intervention, with and without a reflux of material on compression of the dacryocystocele. ${ }^{9,21}$ Therefore, the proximal rupture of a dacryocystocele may be a precursor to an increased risk of dacryocystitis, and is thus useful for the management of a dacryocystocele.

On the other hand, it should be noted that a dacryocystocele with an earlier opening of the distal membrane has a greater risk of severe infection than does congenital nasolacrimal duct obstruction. The reason for that greater risk might be due to the extended spaces in the lacrimal sac, nasolacrimal duct, and nasal cyst, which are favorable environments for the increase of bacterial flora. However, two studies have reported that most cases of acute pediatric dacryocystitis were caused by $\alpha$-hemolytic Streptococcus and Staphylococcus epidermidis, which make up the normal bacterial flora of the nasal lacrimal system, and that common antibiotics are effective treatments. ${ }^{12,14}$ Moreover, Becker suggested that a prophylactic treatment with antibiotics before probing would increase the success rate of the probing twofold. ${ }^{8}$ These reports intimate that medication with appropriate antibiotics to control infection must be initiated first. In all of our patients, there was a spontaneous resolution, even in the patients complicated by dacryocystitis, by controlling the inflammation with topical and systemic antibiotics. The resolution at 15 weeks in our patient 2 described earlier was the oldest case of spontaneous resolution in this study, and was a significantly later resolution than the 8 weeks described 
in earlier reports. ${ }^{9,21,22}$ This finding suggests that there is the possibility of spontaneous resolution for at least 15 weeks after birth.

Except in patients with respiratory distress after birth, we recommend conservative treatment for dacryocystoceles that have a high probability of spontaneous resolution, just as in eyes with congenital nasolacrimal duct obstruction. However, strict attention needs to be paid to patients with proximal rupture of the dacryocystocele. Moreover, the findings of this study show that dacryocystitis that develops from a dacryocystocele is more serious than congenital nasolacrimal duct obstruction, and efficient use of antibiotics during the early stage is recommended. However, it should be noted that the findings of this study, which only involved a small number of cases, merely present the possibility that our suggestions can be a useful benchmark for the treatment of dacryocystoceles, and further investigations are needed.

\section{Acknowledgments}

The authors wish to thank the following participating investigators who provided care for study patients: Kentaro Nunotani, Yasushi Fujita, and Yukihiro Imagawa from the Department of Ophthalmology, Osaka Kaisei Hospital, Osaka, Japan; and Norihiko Ishizaki and Masanori Fukumoto, from the Department of Ophthalmology, Takatsuki Red Cross Hospital, Osaka, Japan. The authors also wish to thank John Bush for reviewing the manuscript.

\section{Disclosure}

The authors report no conflicts of interest in this work.

\section{References}

1. Yazici Z, Kline-Fath BM, Yazici B, Rubio EI, Calvo-Garcia MA, Linam LE. Congenital dacryocystocele: prenatal MRI findings. Pediatr Radiol. 2010;40(12):1868-1873.

2. Shekunov J, Griepentrog GJ, Diehl NN, Mohney BG. Prevalence and clinical characteristics of congenital dacryocystocele. J AAPOS. 2010;14(5):417-420.
3. MacEwen CJ, Young JD. Epiphora during the first year of life. Eye (Lond). 1991;5(Pt 5):596-600.

4. Grin TR, Mertz JS, Stass-Isern M. Congenital nasolacrimal duct cysts in dacryocystocele. Ophthalmology. 1991;98(8):1238-1242.

5. Paysse EA, Coats DK, Bernstein JM, Go C, de Jong AL. Management and complications of congenital dacryocele with concurrent intranasal mucocele. J AAPOS. 2000;4(1):46-53.

6. Pediatric Eye Disease Investigator Group. Resolution of congenital nasolacrimal duct obstruction with nonsurgical management. Arch Ophthalmol. 2012;130(6):730-734.

7. Kakizaki H, Takahashi Y, Kinoshita S, Shiraki K, Iwaki M. The rate of symptomatic improvement of congenital nasolacrimal duct obstruction in Japanese infants treated with conservative management during the 1st year of age. Clin Ophthalmol. 2008;2(2):291-294.

8. Becker BB. The treatment of congenital dacryocystocele. Am J Ophthalmol. 2006;142(5):835-838.

9. Mansour AM, Cheng KP, Mumma JV, et al. Congenital dacryocele. A collaborative review. Ophthalmology. 1991;98(11):1744-1751.

10. Shashy RG, Durairaj VD, Holmes JM, Hohberger GG, Thompson DM, Kasperbauer JL. Congenital dacryocystocele associated with intranasal cysts: diagnosis and management. Laryngoscope. 2003;113(1): $37-40$

11. Wong RK, VanderVeen DK. Presentation and management of congenital dacryocystocele. Pediatrics. 2008;122(5):e1108-e1112.

12. Schnall BM, Christian CJ. Conservative treatment of congenital dacryocele. J Pediatr Ophthalmol Strabismus. 1996;33(5):219-222.

13. Pollard ZF. Treatment of acute dacryocystitis in neonates. J Pediatr Ophthalmol Strabismus. 1991;28(6):341-343.

14. Campolattaro BN, Lueder GT, Tychsen L. Spectrum of pediatric dacryocystitis: medical and surgical management of 54 cases. J Pediatr Ophthalmol Strabismus. 1997;34(3):143-153; quiz 186-187.

15. Rosen WJ, Li Y. Sudoriferous cyst of the orbit. Ophthal Plast Reconstr Surg. 2001;17(1):73-75.

16. Robertson DM, Henderson JW. Unilateral proptosis secondary to orbital mucocele in infancy. Am J Ophthalmol. 1969;68(5):845-847.

17. Hurwitz JJ, Rodgers J, Doucet TW. Dermoid tumor involving the lacrimal drainage pathway: a case report. Ophthalmic Surg. 1982;13(5): 377-379.

18. Jones LT, Wobig JL. Surgery of the Eyelids and Lacrimal System. Birmingham (AL): Aesculapius; 1976.

19. Sevel D. Development and congenital abnormalities of the nasolacrimal apparatus. J Pediatr Ophthalmol Strabismus. 1981;18(5):13-19.

20. Silverman S. Microphthalmos with congenital defect of the lacrimal apparatus. Br J Ophthalmol. 1933;17(6):351-353.

21. Harris GJ, DiClementi D. Congenital dacryocystocele. Arch Ophthalmol. 1982;100(11):1763-1765.

22. Levy NS. Conservative management of congenital amniotocele of the nasolacriminal [sic] sac. J Pediatr Ophthalmol Strabismus. $1979 ; 16(4): 254-256$.
Clinical Ophthalmology

\section{Publish your work in this journal}

Clinical Ophthalmology is an international, peer-reviewed journal covering all subspecialties within ophthalmology. Key topics include: Optometry; Visual science; Pharmacology and drug therapy in eye diseases; Basic Sciences; Primary and Secondary eye care; Patient Safety and Quality of Care Improvements. This journal is indexed on

\section{Dovepress}

PubMed Central and CAS, and is the official journal of The Society of Clinical Ophthalmology (SCO). The manuscript management system is completely online and includes a very quick and fair peer-review system, which is all easy to use. Visit http://www.dovepress.com/ testimonials.php to read real quotes from published authors. 